\title{
Czy filozofia ma coś do zaoferowania zwierzętom? (Rec. D. Dzwonkowska, M. Latawiec, D. Gzyra i in., Filozofia wobec świata zwierząt, Wydawnictwo UKSW, Warszawa 2015, ss. 159)
}

Zwierze ma swoje prawa tak jak człowiek, dajmy mu więc swobodę, a ty, drogi mój druhu w człowieczeństwie, też jeszcze jesteś zwierzęciem, mimo wszystko!

F. Nietzsche

Od kilku lat obserwujemy w Polsce szerokie zainteresowanie problemem praw zwierząt. Nasilające się na ten temat dyskusje motywują przedstawicieli bardzo różnych dziedzin i gałęzi nauki do czynnego zabierania głosu. Etycy wymieniają swoje poglądy z biologami, prawnikami, lekarzami czy psychologami ${ }^{1}$. Spory o prawa zwierząt wyraźnie przypominają debaty nad problemem emancypacji kobiet z przełomu XIX i XX wieku². Pomimo multidyscyplinarnego charakteru tego zagadnienia, wydaje się, że głos filozofii powinien, o ile jeszcze nie jest, być uprzywilejowanym. To filozof bowiemjest tym, kto z natury swego powołania ma dać odpowiedź na podstawowe i najbardziej palące kwestie poruszające ludzki rozum. Taką kwestią z całą pewnością jest problem stosunku człowieka do zwierząt. Jest to bowiem problem pryncypialny. Ściśle powiązany z pytaniem

\footnotetext{
1 Najlepszym przykładem tego stanu rzeczy była zorganizowana przez Przegląd filozoficzny w dniach 5-6 maja 2015 roku konferencja pt. Ludzie i zwierzęta. Równoważnie interesów, w której wzięło udział wielu przedstawicieli bardzo różnych nauk. Na rynku dostępny jest wybór tekstów z tej konferencji (Dziobkowski 2015) 2 Tak twierdzi np. Peter Singer w przełomowej pracy Wyzwolenie zwierząt (Singer 2004).
} 
o samego człowieka: o jego „zwierzęce” pochodzenie, o jego miejsce w świecie, jakość jego życia, którą mierzy się jego stosunkiem do tego, co inne. Zwierzęta wydają się, pomimo tak szerokiego spektrum podobieństw do nas, tym, co inne wobec człowieka.

Autorzy książki mającej wymowny tytuł Filozofia wobec świata zwierząt wydają się być świadomi potrzeby i ważności filozoficznego namysłu nad relacją człowieka i zwierząt. Ich rozważania mają bowiem na celu ustosunkowania się do postawionego przeze mnie na początku pytania o to „czy filozofia ma coś do zaoferowania zwierzętom?”. Z całą pewnością próba podjęta przez autorów jest zasadna. Co do tego nie mam wątpliwości. Chciałbym się jednak przyjrzeć temu, na ile ona się udała.

Prezentowana tu książka składa się z sześciu autorskich rozdziałów, każdy napisany przez innego badacza. Całość poprzedza Wstęp Dominiki Dzwonkowskiej, zaś książkę zamykają pomocne streszczenia w języku angielskim i rosyjskim. Odrobinę doskwiera brak indeksu osób i rzeczowego, co w tego typu wprowadzających publikacjach jest niezwykle pomocne.

Pomimo tego, że książka w tytule nosi słowo filozofia, nie jest do końca jasne, jaką filozofią autorzy się inspirują. Jest to w pewnym stopniu symptomatyczne dla całej publikacji, bowiem niejednokrotnie natrafia się na miejsca, w których najważniejsze pojęcia są używane bez żadnego wyjaśnienia ich znaczenia i rozumienia przez autora. Pewną podpowiedź znajdujemy we Wstępie: „Dotychczasowa etyka skupiała się na kwestii dobra moralnego w kontekście drugiego człowieka. Wszystkie normy etyki dotyczyły relacji człowieka z drugim człowiekiem, podczas gdy kwestia otaczającego człowieka środowiska pozostawała nieznaną i obojętną etycznie" (7) ${ }^{3}$. Wskazówka ta wraz $\mathrm{z}$ informacjami zawartymi w poszczególnych rozdziałach pozwala sądzić, że pod słowem „filozofia” ukrywa się „etyka środowiskowa”. Trudno jednak w książce znaleźć odpowiedź na pytanie o to, dlaczego autorzy nie zatytułowali swojej publikacji bardziej precyzyjnie. Z całą pewnością perspektywa etyki środowiskowej jest tutaj przewodnią.

\footnotetext{
${ }^{3} \mathrm{~W}$ nawiasach podaje numery stron omawianej pozycji.
} 
Jest to perspektywa formalna. Od strony materialnej książka koncentruje się na dyskusji $\mathrm{z}$ „silnie antropocentryczną kulturą, która w całej swej rozciągłości uzasadniała wyższość człowieka" nad zwierzętami (8). Lektura omawianej pozycji pozwala zapytać - co uważam za jedno $\mathrm{z}$ większych teoretycznych osiągnięć tej pracy - na ile antropomorfizm, który wydaje się być warunkiem sine qua non wszelkich debat nad przyznaniem praw zwierzętom, jest ufundowanym na owej antropocentrycznej kulturze.

Michał Latawiec, autor pierwszego rozdziału zatytułowanego Próby uzasadnienia idei ochrony zwierząt, dokonuje przeglądu różnych kulturowo-prawno-filozoficznych aspektów, na tle których rozważa się możliwość uznania praw zwierząt. Szczególnie ważna dla autora wydaje się być perspektywa religijno-biblijna opisująca stosunek człowieka do zwierząt. Od strony informacyjnej rozdział ten jest nie do przecenienia. Słabiej oceniam zaś jego wartość argumentacyjną. Pewne uwagi autora mogą budzić niepokój. Latawiec stwierdza: „Największe problemy będą uwidaczniać się na styku odmiennych kultur. I tak, co dla jednych jest normą, dla innych może być nie do zaakceptowania. Problem ochrony zwierząt wymaga więc podjęcia dialogu" (13). Co do zasadności prowadzenia dialogów nie mam wątpliwości, nie do końca jednak wiem, w jaki sposób odnieść się do uwagi na temat norm. Czy mam ją rozumieć jako wyraz relatywizmu normatywnego? Jeżeli tak, to nie widać tutaj możliwości skonstruowania przekonującej argumentacji etycznej za przyznaniem praw zwierzętom, które to prawa, wydaje się, że powinny mieć uniwersalny charakter analogicznie do praw człowieka. W dalszej części artykułu autor wymieniając pytania dotyczące relacji ludzi do zwierząt, w pewnym sensie dookreśla swoje stanowisko w kwestii norm: „Są to problemy, które domagają się otwartej dyskusji” (20). Czy w takim razie problem normatywności norm ma zostać rozwiązany na drodze społecznego konsensusu, demokratycznie usankcjonowanej dysputy osób uznanych za ekspertów w danej dziedzinie? Jest to stanowisko nieobce wielu współczesnym filozofom (m.in. R. Rorty, J. Habermas), Michał Latawiec jednak nie podaje za nim żadnych 
argumentów. Próżno ich szukać w jego rozważaniach, a szkoda bo na ich przedstawieniu skorzystałaby cała książka.

Kolejny rozdział $O$ zmyślności zwierząt. Rozważania wokót etyki zróżnicowanych natur autorstwa Jacka Lejmana stanowi interesujący komentarz do uwag Plutarcha na temat rozwoju różnych zdolności u zwierząt w zależności od środowiska, w którym żyją. Wydaje się, że człowiek powinien chronić zwierzęta, którą są bardziej zmyślne, czyli takie, które są bardziej do niego podobne. Jak autor sugestywnie pokazuje, na przestrzeni wieków owo podobieństwo było rozumiane rozmaicie. Współcześnie wielu zwolenników antropocentryzmu postuluje potrzebę ustalenia swoistego kryterium hierarchizacji, które „pozwalałoby zachować dotychczasowe wyróżnione miejsce człowieka w świecie. Jak można wnosić z przytoczonych powyżej rozważań, jest nim w dalszym ciągu kwestia rozumu ludzkiego w opozycji do rozumu zwierzęcego" (44). W takim ujęciu o zmyślności decyduje rozumność. Jak Lejman słusznie zauważa, jest to kryterium niewystarczające. Autor dostrzega trudność leżącą u samej podstawy zrównania zwierząt (a przynajmniej ich części) z ludźmi. Niemożliwa bowiem wydaje się etyka, która zakładałaby równe traktowanie człowieka i np. lisa. Lejman sugeruje, że skuteczne działania na rzecz ochrony zwierząt, które już postulują pewną formę etyki, powinny odrzucić myślenie w kategoriach „mniejszego” lub „większego” podobieństwa do ludzi. Winny one raczej „uwzględniać dobro danego zwierzęcia, które można odczytać z jego etogramu (biogramu)” (45). Z etogramu możemy wnioskować o dobrostanie zwierzęcia i na tej podstawie nadawać mu prawa. Pojęcie zwierzęcego biogramu, nazywanego przez Lejmana etogramem, zaczerpnięte jest z prac Earla W. Counta. Jak wykazali uczniowie uczonego, pojęcie to jest niejasne. Podobnie niejasne jest tutaj pojęcie dobrostanu, które zakłada jakąś chociażby wstępną wiedzę na temat stanów psychicznych zwierząt, a jak sam Lejman zauważa, zdobycie jej jest praktycznie niemożliwe. Czy w takim razie skazani jesteśmy mimo wszystko na poszukiwanie ostatecznie arbitralnych cech wspólnych nam i zwierzętom? Zdaniem autora rozdziału człowiek powinien zmienić swoje nastawienie wobec świata i przestać traktować siebie jako jego „władcę”, ale raczej 
jako jego „część”. W takim ujęciu pomiędzy nami i zwierzętami nie ma istotnych różnic. Owa zmiana nastawienia jest możliwa jeżeli przyjmie się „globalną politykę ekologiczną”, opartą na wiedzy biologicznej i etycznych rozważaniach. Nie trudno się zgodzić $\mathrm{z}$ autorem powyższych stwierdzeń, jednak moją wątpliwość budzi ich hasłowy charakter. Nie dostrzegam w jaki sposób owa "globalna polityka ekologiczna" ma wpłynąć na działania i przekonania poszczególnych ludzi czy grup społecznych. Brakuje mi tutaj normatywnego wymiaru takiego przedsięwzięcia. Sądzę bowiem, że problem nadania praw zwierząt nie wynika z niewiedzy i braku świadomości, ale $\mathrm{z}$ braku widzenia w zwierzęciu innego, któremu należy się pewna forma szacunku. Najlepszą ilustracją dla mojej myśli są ludy pierwotne zamieszkujące Afrykę bądź Amerykę Południową, które pomimo braku wiedzy biologicznej i ekologicznej, wykazują duże większe poszanowanie dla tego, co żyje, niż posiadający wykształcenie i „wyższą” kulturę przedstawiciele tzw. cywilizowanych państw. Cały ten problem - jak słusznie podkreślają David Gunkel i Mark Coeckelbergh i co w pewnym stopniu chciał wykazać Jacek Lejman - polega bowiem na niewłaściwie zadanym pytaniu w punkcie wyjścia. Mianowicie: zamiast pytać „Jakie własności posiadają zwierzęta, że możemy je porównywać z ludźmi?” należy zapytać o „warunki możliwości uznania danej istoty za podmiot moralności” (Coeckelbergh, Gunkel 2014: 716). Ostatnie pytanie wiążę z próbą potraktowania zwierząt jako takich istot, które $\mathrm{z}$ racji swojego istnienia, już potencjalnie należą wraz z ludźmi do jednej wspólnoty etycznej ${ }^{4}$.

Krótko o „słabej” wersji antropocentryzmu Bryana G. Nortona to trzeci rozdział monografii, którego autorem jest Mirosław Twardowski. Twardowski, który omawiając poglądy bohatera swoich rozważań, w interesujący sposób pokazuje jak, pomimo powszechnej

\footnotetext{
${ }^{4}$ Coeckelbergh i Gunkel wiążą nadanie praw zwierzętom z przypisanie im levinasowej Twarzy Innego. Ten kto posiada twarz zostaje automatycznie włączony do relacji etycznej (Coeckelbergh, Gunkel: 721-723). Tak jak zgadzam się z ich koncepcją zmiany zapytywania, tak nie zgadzam się z takim jej rozwiązaniem. Niestety brak tu miejsca na szczegółowe wyjaśnienie tej kwestii.
} 
i zdecydowanej krytyki, można bronić antropocentryzmu w jego „słabszej” wersji zaproponowanej przez Nortona. Norton próbuje pogodzić swój antropocentryzm z ideą ochrony przyrody, rezygnując jednocześnie $\mathrm{z}$ języka biocentryzmu. W standardowej wersji antropocentryzm to „pogląd, według którego nie istnieje żadna wartość niezależna od ludzkiego doświadczenia (Callicott 1992: 1465). W takim ujęciu jest on odrzucany m. in. Petera Singera i Toma Regana jako wyraz niesłusznego uznania przez człowieka swojego miejsca w świecie jako uprzywilejowanego ${ }^{6}$. Tak rozumianemu antropocentryzmowi Norton przeciwstawił swoją „słabszą” wersję według której interesy ludzi i zwierząt są ostatecznie bardzo podobne, bowiem właściwe zrozumienie zależności człowieka od przyrody, pozwoli zrozumieć, że jej prawa są w jakimś stopniu prawami ludzi. Natura bowiem nie ma być „zaspokajaczem” ludzkich wartości, ale źródłem inspiracji w ich tworzeniu. Zdaniem Twardowskiego zmiana w postrzeganiu roli natury ma sprowokować człowieka do tego by stał się lepszy. Widoczne jest tutaj myślenie życzeniowe, które jako pierwszy w dziejach myśli wyraził Platoński Sokrates wierząc, że sama znajomość dobra wystarczy, aby człowiek stał się lepszy. Jak wiemy z doświadczenia, nie istnieje konieczny związek zachodzący pomiędzy posiadana wiedzą a wyrażanymi przekonaniami. Twardowski opierając się na rozważaniach Nortona w pewnym sensie rozwiązuje powyższy problem, mówiąc, że „,zasady etyki środowiskowej nie mogą, w ocenie B.G. Nortona, wywodzić się z indywidualistycznych systemów etyki, które obecnie są w modzie (Norton 1984:1417). Żaden system etyczny, który jest zasadniczo indywidualistyczny (...) nie może (...) oferować skutecznej pomocy etycznej w zakresie polityki środowiskowej" (67). Zaletą propozycji Nortona jest w taki razie jej nieindywidualistyczne podejście etyczne. Co to znaczy? Z rozważań Twardowskiego wyłania się obraz myślenia globalnego, w którym nie

\footnotetext{
5 Przytaczam za Mirosławem Twardowskim (60).

6 Dominika Dzwonkowska mówi wręcz o „antropocentrycznym paradygmacie kultury zachodniej" (9).

7 Przytaczam za Mirosławem Twardowskim (67).
} 
rozprawiamy nad jednostkami, ale nad populacjami czy wręcz gatunkami. Oddajmy słowo Nortonowi: „Utrzymywanie gatunku ludzkiego jest dobrą rzeczą, ponieważ Wszechświat zawierający ludzką świadomość jest lepszy od Wszechświata, który jest jej pozbawiony. Takie twierdzenie implikuje, że obecne pokolenia muszą przejawiać troskę o przyszłe pokolenia. Muszą podejmować kroki, by uniknąć wyginięcia gatunku oraz pozostawić dość stabilną bazę surowców tak, by przyszłe generacje nie cierpiały ubóstwa" (Norton 1984: $143^{8}$ ). $\mathrm{Z}$ punktu widzenia tzw. polityki środowiskowej jest to z pewnością zalecenie interesujące, jednak nie umiem dostrzec jego praktycznego zastosowania, tzn. na ile tak sformułowana etyka może mi pomóc znaleźć odpowiedź na konkretne pytanie, zadane w konkretnym miejscu i czasie, takie jak na przykład: „Zabić czy nie?”. Nie widzę również żadnego filozoficznego uzasadnienia tezy, że „Wszechświat zawierający ludzką świadomość jest lepszy od Wszechświata, który jest jej pozbawiony"? Ogólny charakter tego stwierdzenia aż razi. Chciałbym podkreślić, że wielką zasługą autora jest szczegółowe przeanalizowania propozycji Briana Nortona, podkreślające jej mocne i słabe strony oraz możliwości potencjalnej krytyki, brakuje mi jednak krytycznego namysłu nad językiem używanym przez Nortona ${ }^{9}$ oraz bardzo ogólnym charakterem formułowanych przez niego twierdzeń.

Czwarty rozdział zatytułowany Znaczenie empatii $i$ współczucia $w$ trosce o jakość życia zwierząt w moim odczuciu stanowi centralną część monografii. Dominika Dzwonkowska, która jest jego autorką, w sposób przekonujący pokazuje konieczność uwzględnienia „kwestii emotywnego zaangażowania obrońców praw i dobrostanu zwierząt" (82). Jej celem jest „próba oceny empatii i współczucia jako motywacji do ochrony praw zwierząt bądź inspiracji do działania na rzecz poprawienia ich losu” (82). Rozdział ten, jak wspomniałem, można uznać za wyróżniony, bowiem Dzwonkowska porusza tutaj problem doświadczenia jako tego, co może stanowić podstawę do postulowania

\footnotetext{
8 Przytaczam za Mirosławem Twardowskim (67).

9 Chodzi mi m.in. o takie metaforyczne zwroty jak: „nauczyciel ludzkich wartości”, „przyjąć wartość”, czy „Zaspokajacz potrzeb”.
} 
przyznania praw zwierzętom. W jej przekonaniu owym doświadczeniem jest przeżycie empatii, które odróżnia od współczucia. Jest to o tyle istotne, że wydaje się, iż wielokrotnie ludzie mylą oba fenomeny. Autorka opierając się na rozważaniach Aaltola i Chismara powiada: „empatia nie jest realnym odczuciem określonego stanu, tylko swego rodzaju quasi-doświadczeniem, przedstawieniem, podobnie jak wspomnienie czy wyobrażenie. W tym sensie jawi się raczej jako specyficzne odczucie niż realne przeżycie stanów wewnętrznych drugiego. Współczucie, z kolei, nie oznacza wcale empatycznych odczuć skierowanych wobec obiektu współczucia, ale wiąże się z pozytywnym nastawieniem względem osoby, która potrzebuje współczucia lub oznacza troską o tę osobę" (87). Dzwonkowska uważa, że tak rozumiana empatia stanowi idealną podstawę dla etyki obejmującej ludzi i inne nie-ludzkie zwierzęta, bowiem umożliwia ona bliższą zażyłość $\mathrm{z}$ innymi i utożsamienie się $\mathrm{w}$ pewnym stopniu $\mathrm{z}$ ich odczuciami. Problemem jaki tutaj dostrzega, jest kwestia znajomości stanów wewnętrznych innych podmiotów. Jest to klasyczny problem każdej teorii intersubiektywności odnoszącej się do pojęć empatii albo wczucia. Słusznie powołuje się tutaj na poglądy Edith Stein, która w napisanej pod kierunkiem Edmunda Husserla pracy doktorskiej O zagadnieniu wczucia (Stein 1988), stwierdziła, że empatia to specyficzna forma wewnętrznej intuicji, która pozwala na przypisania innemu z pewną dozą pewności danego stanu psychicznego. Szkoda tylko, że autorka tego rozdziału nie zechciała zagłębić się bardziej w meandry fenomenologicznej nauki o wczuciu. Jej praca bowiem wiele by zyskała na przykład w konfrontacji z koncepcja Romana Ingardena, tłumaczącą jak możliwe jest „poznawanie cudzych stanów psychicznych” za pośrednictwem cielesności i zachowania (Ingarden 1971: 407-427). Niezależnie od tego Dzwonkowska „omija” problem wczucia i uznaje empatię za cechę, która wyróżnia ssaki na tle innych zwierząt. Jest to rozwiązanie dobre, ponieważ pokazuje pewną wspólnotę zachodzącą pomiędzy ludźmi, a tą grupą zwierząt, która wydaje się być najbardziej uprzywilejowana do przyznania jej praw. Jednak wikła ono autorkę w bardzo trudną dyskusję nad tym, czy zwierzęta faktycznie posiadają umiejętność empatii lub współczucia. Zdaniem Fransa de Waal 
nic nie stoi na przeszkodzie, by uznać część zwierząt za empatyczne, bowiem tylko ludzki opór, nazywany przez niego „uprzedzeniem antropocentrycznym", nie pozwala nam na dostrzeżenie u zwierząt tych umiejętności (de Waal 2014: 27). Przeciwko temu można łatwo podać argument, który sformułował Daniel Dennett: „Psychologowie często odwołują się do Kanonu Oszczędności Lloyda Morgana, który można uznać za szczególny przypadek Brzytwy Ockhama. Kanon zakłada, że powinniśmy przypisywać organizmowi tylko tyle inteligencji lub świadomości, lub umysłu, ile wystarczy do wyjaśnienia jego zachowania (Dennett 1975: 182, cyt. za Hołówka 2015: 82-83). Zgodnie z sugestią Dennetta nie wydaje się, żeby empatia była konieczną zdolnością tłumaczącą zachowania psów albo szympansów. Dominika Dzwonkowska dostrzegając podobne trudności, uznaje w swoich dalszych rozważaniach empatię za cnotę środowiskową, pozwalająca na zbudowanie środowiskowej etyki troski. Zamysł jest mniej więcej taki: człowiek jako istota empatyczna troszczy się o inne stworzenia, bowiem wczuwając się w ich położenie, czuje się za nie odpowiedzialny. Z tego to powodu autorka stwierdza: „Aby móc całościowo ukazać problem, należałoby uwzględnić różny charakter relacji człowiek - zwierzę. O ile nieliczni odczuwają wobec cierpienia zwierząt hodowlanych współczucie tak silne, że popycha ich ono do ochrony zwierząt, rezygnowania $z$ diety mięsnej, a nawet odzwierzęcej lub do całkowitej rezygnacji z jakichkolwiek produktów odzwierzęcych, to każdy, poza drobnymi wyjątkami, odczuwa przywiązanie i cały szereg pozytywnych uczuć wobec zwierząt domowych, których jest właścicielem” (97) i dodaje: „Stąd kluczowe znaczenie miałoby rzetelne informowanie konsumentów o sposobie wyprodukowania danego produktu, być może informacja o tym, że produkt był testowany na zwierzętach lub że niektóre jego składniki zostały pozyskane w sposób budzący wątpliwości etyczne" (96). Wraca tutaj idea, obecna już w innych rozdziałach tej pracy, konieczności dokształcenia ludzi i wyrobienia w nich zdolności współczucia. Budzi to jednak moje wątpliwości. Wielu ludziom sama informacja o sposobie zadawania cierpienia zwierzętom, o eksperymentach na nich wykonywanych, czy o wykorzystywaniu ich w celach rozrywkowych nie wystarcza 
do tego, by zmienili swój sposób życia i podejście do innych żywych stworzeń. Potrzebne są zmiany prawne. Jest to oczywiście komunał. Problem wiąże się z podstawą, która owe zmiany wywoła.

Propozycja Dominiki Dzwonkowskiej jest bardzo dobra, pomimo, że natrafia na szereg trudności, których część tutaj podkreśliłem. Daje ona impuls do dalszych badań i otwiera nowe perspektywy. Wydaje mi się, że gdyby zmodyfikować koncepcję Dzwonkowskiej, byłaby ona dużo mniej aporetyczna. Sugeruję, aby skoncentrować się jedynie na ludzkim wymiarze empatii. Co przez to rozumiem? Po pierwsze nie posiadamy odpowiednich świadectw i dowodów empirycznych potwierdzających istnienie tego rodzaju zdolności nawet u naszych najbliższych ewolucyjnie „krewnych”, jakimi są małpy naczelne. Nie chcę przez to powiedzieć, że małpy nie współodczuwają tylko, że badania nad ich „moralnością” i empatią są silnie „naznaczone” intencjami osób je przeprowadzającymi ${ }^{10}$. Wynik eksperymentów lub obserwacji jest w pewnym stopniu zdeterminowany założeniami i językiem, które przyjmuje badacz. Po drugie - jest to argument ważniejszy: do tego, aby empatię uznać za podstawę etyki troski, wcale nie jest nam potrzebne przekonania o empatycznych zdolnościach zwierząt ${ }^{11}$. Na podstawie tego, że ja komuś współczuję lub inny wzbudza we mnie empatyczne reakcje, mogę zająć pewną postawę, którą określę mianem zobowiązania. Przykładowo: jeżeli czuję, że zwierzęta, które hoduję mogą cierpieć, to mogę zobowiązać się do lepszego ich traktowania. Moja empatia jest wystarczająca do przyjęcia pewnego zobowiązania. Ktoś o kim wie, że potrzebuje pomocy bo cierpi, może mnie utwierdzać w przekonaniu, że nic złego mu się nie dzieje, ja jednak opierając się na swojej empatii, będę czuł się zobowiązany mu pomóc. Wydaje się zatem, że można zbudować etykę

\footnotetext{
${ }^{10}$ Moim zdaniem przykład takiej postawy znajdujemy w pracach m.in. Fransa de Waal.

${ }^{11}$ Wiąże się to również z tym, że każda ludzka etyka jest „etyką istot mówiących”. Pogląd ten uzasadniam w artykule Czy pytanie o myślenie zwierząt jest pytaniem z zakresu etyki? Dyskusja na tle poglądów Kartezjusza (Piekarski 2015: 219-236).
} 
obejmującą ludzi i inne zwierzęta na pojęciach (ludzkiej) empatii i zobowiązania ${ }^{12}$.

Dariusz Gzyra jest autorem piątego rozdziału pracy Filozofia wobec zwierzat. Nosi on tytuł Teoria praw zwierząt Toma Regana a etyka środowiskowa. Dobrze, że Gzyra omawia postać Toma Regana, wydaje się bowiem, że jest to myśliciel wciąż niewystarczająco znany w Polsce. Koncepcje Regana - co podkreśla autor - zasadza się na polemice z wszystkimi bardziej znaczącymi teoriami uzasadniającymi konieczność nadania uprawnień zwierzętom. Regan, podobnie jak Norton, powiada, że prawa zwierząt są ściśle powiązane z prawami ludzi. Rozumie to jednak inaczej niż twórca „słabej” wersji antropocentryzmu. Zdaniem Regana każdy argument na rzecz praw zwierząt jest jednocześnie argumentem na rzecz praw człowieka. Podmiotem praw są jednostki i to ich prawa są nadrzędne względem praw grup czy instytucji. Jednak jak słusznie zauważył Regan istnieje pewna „luka leksykalna”, która wskazuje na potrzebę wprowadzenia pojęcia, które „byłoby podstawą równości praw i oddawało szczególny (w tym ponadgatunkowy) zestaw istotnych moralnie podobieństw" (107). Owym pojęcie jest „podmiot życia (subject-of-a-life). Niestety Dariusz Gzyra nigdzie nie tłumaczy, co owe dość abstrakcyjne pojęcie oznacza. Co w praktyce wiąże się z tym, że koncepcja Regana staje się „nieprzejrzysta”. Dowiadujemy się bowiem, że podmioty życia posiadają wartość przyrodzoną (inherent value). Jednak i ta kategoria nie zostaje wyjaśniona. Bardzo ciekawa jest analiza krytyki, którą przeprowadził Regan nad etyką Ziemi Aldo Leopolda, wiążąc ją wprost Z „faszyzmem środowiskowym” (110). Jest to pouczająca przestroga dla osób popadających w skrajny biocentryzm. Na koniec swoich rozważań Gryza pokazuje związek koncepcji Regana z zagadnieniami etyki środowiskowej oraz zapytuje o możliwość przejścia od uprawnień jednostek moralnych do nadawania uprawnień innym podmiotom życia takim, jak rośliny czy owady. Regan na tę ostatnią kwestię odpowiada dość sceptycznie i tajemniczo: „Nie wystarczy przyznać przyrodzoną wartość gatunkom, ekosystemom czy biosferze. Trzeba

\footnotetext{
${ }^{12}$ Wiecej na temat pojęcia zobowiązania por. Brandom 1994.
} 
też mieć nieodparty argument, żeby to zrobić. Nie tylko nikt go nie podał (...) wierzę, że nie może być podany" (Regan 2004: $\mathrm{xli}^{13}$ ). Do takiej konstatacji trudno się jednak odnieść.

Ostatni, szósty rozdział monografii zatytułowany $O$ społecznej i naukowej kondycji bioetyki w Rosji. Sylwetka Tatiany Pawłowej na tle innych obrońców zwierząt różni się zasadniczo od pozostałych części książki. Jest to szkic biograficzno-problemowy. Jego autorka Justyna Tymieniecka-Suchanek - opowiada czytelnikom historię Tatiany Pawłowej, pierwszej rosyjskiej badaczki relacji zachodzących pomiędzy ludźmi i zwierzętami. Zawiłe losy bohaterki żyjącej w Związki Radzieckim przeplatają się tutaj z jej interesującymi poglądami na temat zwierząt i ich praw. Pawłowa była prekursorem rosyjskiej bioetyki oraz współczesnego ruchu wyzwolenia zwierząt. Tymieniecka-Suchanek na marginesie analizy poglądów Pawłowej, opisuje skomplikowane dzieje narodzin ruchu na rzecz praw zwierząt i ekologii w ZSRR. Niezwykle wartościowym i unikatowym wątkiem na światową skalę było zaangażowania Rosjanki w obronę dzikich zwierząt, czyli takich, których losem nie zainteresowała się wielu bioetyków z tzw. Zachodu. Kluczowe dla Pawłowej było racjonalne regulowania stosunków człowieka z przyrodą, której człowiek jest współmieszkańcem, tak jak i zwierzęta. Wartość badań Justyny Tymienieckiej-Suchanek polega na szczegółowej analizie myśli tej, wydaje się, niedocenionej postaci ruchów prozwierzęcych oraz na przedstawieniu, wciąż mało znanej w naszym kraju, historii współczesnej filozofii rosyjskiej.

\section{Zakończenie}

Omawiana przeze mnie książka pomimo czasami pojawiających się miejscach słowach mojej krytyki, jest pozycją cenną i godną polecenia. Zadecydowały o tym trzy względy. Po pierwsze publikacja, co zasygnalizowałem na samym początku mojej recenzji, stanowi w pewnym sensie wprowadzenie w zawiłą problematykę praw zwierząt, będąc

\footnotetext{
${ }^{13}$ Przytaczam za Dariuszem Gryzą (117).
} 
przeglądem podstawowych problemów i stanowisk oraz zwięzłą ich prezentacją (praca nie jest długa - liczy sobie zaledwie 159 stron). Po drugie jej interdyscyplinarny charakter (rozdziały są pisane przez przedstawicieli trzech gałęzi współczesnej humanistyki: filozofii, filologii oraz ochrony środowiska), ukazuje konieczność prowadzenia szerokiego dialogu angażującego zarówno humanistów jak i przyrodników, co samo w sobie stanowi o wielkiej problematyczności dyskusji nad równouprawnieniem zwierząt. I na koniec sprawa najważniejsza słabości omawianych stanowisko, niejasności pojęciowe, hipotetyczny charakter twierdzeń, co starałem się czasami uwypuklić, stanowią najlepsze potwierdzenie konieczności prowadzenia tego typu analiz. Jak nietrudno dostrzec, przedmiot, który budzi tyle kontrowersji, zamętu językowego i sporów, sam ujawnia swoją problematyczność, tym samym motywując badaczy do mozolnego wysiłku jego zbadania i poznania. Na koniec powiem tylko, że jeżeli ktoś interesuje się zagadnienia równouprawnienia zwierząt, ich poszanowania i rolą człowieka w środowisku, powinien sięgnąć po Filozofię wobec zwierząt.

\section{Bibliografia}

Brandom R.B., 1994, Making It Explicit: Reasoning, Representing, and Discursive Commitment, Harvard University Press.

Callicott J.B., 1992, Moral Considerability Extraterrestrial Life, w: E.C. Hargroveb (red.), The Animal Rights/Environmental Ethics Debate. The Environmental Perspective, State University of New York Press, New York, s. 137-150.

Coeckelbergh M., Gunkel D., 2014, Facing Animals: A Relational, Other-Oriented Approach to Moral Standing, w: Journal of Agricultural and Environmental Ethics, 5(27), s. 715-733.

Dennett D., 1975, Conditions of Personhood, w: A. O. Rorty (red.) The Identity of Persons, University of California Press, Berkeley, s. 175-196.

De Waal F., 2014, Bonobo i ateista. W poszukiwani humanizmu wśród naczelnych, przeł. K. Kornas, Copernicus Center Press, Kraków. 
Dziobkowski B. (red.), 2015, Przegląd Filozoficzny. Nowa Seria, 2(94)24, Wydawnictwo PAN (monograficzny numer zatytułowany Ludzie i zwierzęta).

Hołówka J., 2015, Czy istnieja zwierzęta ze statusem osoby?, w: Przegląd Filozoficzny. Nowa Seria, 2(94)24, s. 65-88.

Ingarden R., 1971, O poznawaniu cudzych stanów psychicznych, w: U podstaw teorii poznania, PWN, Warszawa, s. 407-427.

Norton B.G., 1984, Environmental Ethics and Weak Anthropocentrism, w: Environmental Ethics, t. 6, s. 131-148.

Regan T., 2004, The Case for Animal Rights, University of California Press, Berkeley.

Singer P., 2004, Wyzwolenie zwierząt, przeł. A. Alichniewicz, A. Szczęsna, PIW, Warszawa.

Stein E., 1988, O zagadnieniu wczucia, przeł. D. Gierulanka, J. F. Gierula, Znak, Kraków.

Piekarski M., 2015, Czy pytanie o myślenie zwierząt jest pytaniem zzakresyetyki? Dyskusja na tle poglądów Kartezjusza, w: Przegląd Filozoficzny. Nowa Seria, 2(94)24, s. 219-236.

Michał Piekarski Instytut Filozofii, UKSW 